\title{
Oncogene-dependent apoptosis in extracts from drug-resistant cells
}

\author{
Howard O. Fearnhead, ${ }^{1,3}$ Mila E. McCurrach, ${ }^{1}$ Jason $\mathrm{O}^{\prime}{ }^{\text {Neill, }}{ }^{2}$ Kam Zhang, ${ }^{2}$ Scott W. Lowe, ${ }^{1}$ and \\ Yuri A. Lazebnik ${ }^{1,3}$ \\ ${ }^{1}$ Cold Spring Harbor Laboratory, Cold Spring Harbor, New York 11724 USA; ${ }^{2}$ Fred Hutchinson Cancer Research Center, \\ Seattle, Washington 98104 USA
}

\begin{abstract}
Many genotoxic agents kill tumor cells by inducing apoptosis; hence, mutations that suppress apoptosis produce resistance to chemotherapy. Although directly activating the apoptotic machinery may bypass these mutations, how to achieve this activation in cancer cells selectively is not clear. In this study, we show that the drug-resistant 293 cell line is unable to activate components of the apoptotic machinery-the ICE-like proteases (caspases)-following treatment with an anticancer drug. Remarkably, extracts from untreated cells spontaneously activate caspases and induce apoptosis in a cell-free system, indicating that drug-resistant cells have not only the apoptotic machinery but also its activator. Comparing extracts from cells with defined genetic differences, we show that this activator is generated by the adenovirus E1A oncogene and is absent from normal cells. We provide preliminary characterization of this oncogene generated activity (OGA) and show that partially purified OGA activates caspases when added to extracts from untransformed cells. We suggest that agents that link OGA to caspases in cells would kill tumor cells otherwise resistant to conventional cancer therapy. As this killing relies on an activity generated by an oncogene, the effect of these agents should be selective for transformed cells.
\end{abstract}

[Key Words: Apoptosis; cancer; oncogenes; drug resistance; caspases; cell-free assays]

Received December 16, 1997; revised version accepted March 26, 1997

The failure to effectively and selectively eliminate cancer cells is a major problem of cancer therapy. Nonetheless, most mammalian cells, including those that give rise to cancer, have an intrinsic machinery whose function is to carry out cell suicide. Activation of this execution machinery results in apoptosis, a comprehensive process that can quickly eliminate large numbers of cells without triggering adverse responses such as inflammation. The efficiency of such killing prompts the examination of the apoptotic execution machinery as a potential tool to kill cancer cells.

Indeed, many anticancer drugs kill cells by activating the apoptotic machinery. However, this killing is inefficient as activation is indirect. The direct effect of these drugs is cell damage, such as DNA breaks or cell cycle aberrations (Hickman 1992), which then triggers signaling pathways that activate the execution machinery and eventually lead to cell death. However, alterations in the pathways linking the cell damage to the execution machinery, such as p53 mutations (Lowe et al. 1993), are common in cancer cells. Therefore, a cancer cell may fail to die not because the drug does not induce cell damage but because the information about this damage fails to reach the execution machinery of apoptosis (Dive and

${ }^{3}$ Corresponding authors.

E-MAIL fearnhea@cshl.org; lazebnik@cshl.org; FAX (516) 367-8461.
Hickman 1991). In principle, agents that directly activate the execution machinery should bypass alterations that prevent apoptosis and kill cells that are otherwise resistant to cancer therapy. However, how to activate the apoptotic machinery directly and selectively in cancer cells is not clear.

An essential component of the apoptotic machinery is a family of cysteine proteases termed caspases (formerly known as interleukin-1 $\beta$ converting enzyme (ICE)-like proteases) (Martin and Green 1995; Alnemri et al. 1996; Chinnaiyan and Dixit 1996). These proteases are expressed as inactive precursors that are activated by proteolytic processing. Despite their vital role in apoptosis, how caspase activation is regulated is not known. Furthermore, how this activation leads to highly coordinated cell destruction is also poorly understood. Nevertheless, the irreversible nature of proteolysis suggests that activation of caspases is a critical step in apoptosis and, therefore, is an attractive target for drugs that directly activate the apoptotic machinery.

A basis for selective activation of caspases in cancer cells may lie in the mechanisms intrinsic to carcinogenesis. A number of oncogenes, when expressed in cells, induce apoptosis (Harrington et al. 1994). However, transformed cells may survive and give rise to cancer because apoptosis is suppressed, for example, by overexpression of $\mathrm{Bcl} 2$, an inhibitor of apoptosis (Hacker and Vaux 1995). Such suppression not only promotes the sur- 
vival of cancer cells but also confers resistance to chemotherapeutic drugs that kill by inducing apoptosis (Lowe et al. 1993). Whether the proapoptotic activity of oncogenes is abolished by proteins like $\mathrm{Bcl} 2$ or whether it becomes latent is not known. Should this activity be present, even in a latent form, it may be exploited to selectively kill transformed cells. For example, agents that would link this activity to the apoptotic machinery would not harm untransformed cells that have the machinery but lack the oncogene-induced activity.

Cells expressing the adenovirus E1A and E1B oncogenes provide a tractable model that mimics how oncogenic changes can modulate apoptosis during tumorigenesis and in response to anticancer agents (Lowe et al. 1993, 1994). ElA promotes proliferation and, like many other oncogenes that deregulate the cell cycle, also promotes apoptosis (White 1993) and renders E1A-expressing cells highly sensitive to anticancer drugs (Lowe et al. 1993). E1A-induced apoptosis is prevented by products of E1B, allowing oncogenic transformation (Rao et al. 1992) and conferring drug resistance (Subramanian et al. 1993). Here we provide biochemical evidence that cells expressing $\mathrm{E} 1 \mathrm{~A}$ retain a latent proapoptotic activity even when E1B is coexpressed.

As an experimental model, we used the 293 cell line that was derived from human embryonic kidney cells following transfection of adenovirus 5 DNA /Graham et al. 1977). These cells express both E1A and E1B and are highly resistant to multiple anticancer drugs. However, we found that extracts from these cells spontaneously activated endogenous caspases and induced apoptosis in a cell-free system. Using extracts from primary mouse embryo fibroblasts (MEFs) and MEFs transformed with E1A or E1A/E1B, we demonstrated that spontaneous caspase activation in the extracts required expression of E1A. Following partial purification of the E1A-generated activity, we showed that this activity induced caspase activation when added to extracts from untransformed cells. We suggest that this activity is a potential target for drugs that will selectively kill transformed cells.

\section{Results}

\section{3 cells are resistant to apoptosis}

293 cells are highly resistant to multiple anti-cancer drugs. For example, the chemotherapeutic drug etoposide did not induce morphological changes of apoptosis in 293 cells at the concentrations sufficient to kill Jurkat cells, a drug-sensitive tumor cell line (Fig. 1A). To determine whether etoposide treatment induces biochemical changes of apoptosis, we examined the activity of caspases, which are essential components of the apoptotic machinery (Martin and Green 1995; Alnemri et al. 1996; Chinnaiyan and Dixit 1996). Active caspases were visualized by affinity labeling using a biotin-labeled specific inhibitor, biotin-Tyr-Val-Ala-Asp-acyloxymethylketone, (biotin-YVAD-amk) that irreversibly binds to active caspases (Thornberry et al. 1994). Cells were lysed in the presence of biotin-YVAD-amk and incubated to label caspases. The labeled caspases were separated by
A
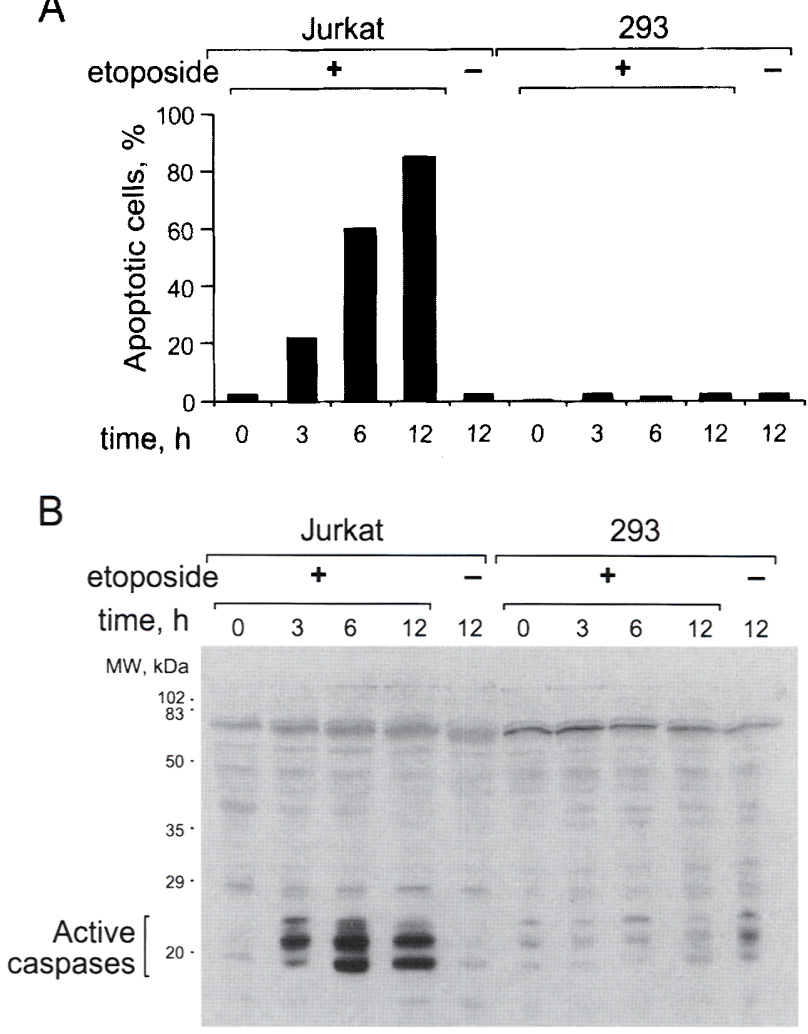

Figure 1. 293 cells are resistant to drug-induced apoptosis. 293 or drug-sensitive Jurkat cells $\left(1 \times 10^{5} / \mathrm{ml}\right)$, used as a control, were incubated with or without etoposide $(50 \mu \mathrm{M})$. (A) 293 cells treated with etoposide do not acquire apoptotic morphology. The percentage of cells with apoptotic chromatin condensation is shown. At least 300 cells were counted per sample. (B) 293 cells treated with etoposide do not contain active caspases. At the indicated times, cells incubated with or without etoposide were lysed in the presence of biotin-YVAD-amk, an affinity probe that binds irreversibly to the catalytic center of active caspases but not caspase precursors (Thornberry et al. 1994). Labeled caspases were visualized using avidin-biotin detection system as described in Materials and Methods.

SDS-PAGE, transferred to a membrane, and visualized using an avidin-biotin detection system and enhanced chemiluminescence. No active caspases were detected in etoposide-treated 293 cells (Fig. 1B), whereas multiple active caspases were detected in etoposide-treated Jurkat cells, which was consistent with the morphological manifestations of apoptosis. These caspases were identified as multiple forms of CPP32 and Mch2 (Faleiro et al. 1997). Thus, in 293 cells drug treatment failed to activate caspases and induce apoptosis.

\section{Extracts from 293 cells induce apoptosis in a cell-free} system

The failure to undergo apoptosis upon drug treatment could be caused by defects in signaling pathways leading to the execution machinery of apoptosis or by inactivation of the machinery itself. To distinguish between 
these possibilities, we obtained extract from 293 cells and tested it in a cell-free system. In such systems, extracts from apoptotic cells induce apoptotic changes in isolated nuclei (apoptosis in vitro), whereas extracts from untreated cells do not (Lazebnik et al. 1994; Martin et al. 1995; Enari et al. 1996). Like apoptosis in vivo, apoptosis in vitro requires caspase activity that is absent in extracts from untreated cells. Unexpectedly, an extract prepared from untreated 293 cells induced apoptosis in vitro. Virtually all isolated nuclei added to the 293 extract underwent morphological changes typical of apoptosis within an hour incubation at $37^{\circ} \mathrm{C}$ (Fig. 2A). Apoptosis in vitro was prevented by biotin-YVAD-amk, a caspase inhibitor, indicating a requirement for caspase activity. Thus, 293 cells retained a functional apoptotic machinery. However, this result was puzzling: Although extracts from 293 cells induced apoptosis in vitro, 293 cells were unable to activate caspases and undergo apoptosis.

Caspases are spontaneously activated in extracts from 293 cells

The observation that apoptosis in vitro was inhibited by treating the 293 extract with a caspase inhibitor was consistent with the role of caspases in apoptosis and also indicated that caspases were active in this extract. Because caspases were inactive in intact 293 cells, they may have been activated during either extract preparation or subsequent incubation in the cell-free system. To distinguish between these possibilities, we followed caspase activation in the 293 extract. Caspase activity was measured either by use of a fluorogenic caspase substrate (Nicholson et al. 1995; Enari et al. 1996) (Fig. 2B) or by visualizing active caspases by affinity labeling (Thornberry et al. 1994; Faleiro et al. 1997) (Fig. 2C). In addition, processing of CPP32, a caspase thought to participate in apoptosis (Nicholson et al. 1995), was examined by immunoblotting (Fig. 2D). CPP32, like other caspases, is expressed as an inactive precursor and proteolytically processed during activation. 293 extracts had no detectable caspase activity and CPP32 was present as an inactive precursor. If the extracts were kept on ice, caspases remained inactive for up to $24 \mathrm{hr}$ (data not shown). However, incubation of the extract at $37^{\circ} \mathrm{C}$ resulted in caspase activation as measured by the fluorogenic assay, which detected a 250 -fold increase in caspase activity (Fig. 2B). Consistent with this result, affinity labeling revealed activation of multiple caspases (Fig. 2C), one of which was CPP32, as detected by immunoblotting (Fig. 2D). Thus, caspases were extracted from 293 cells as precursors and were activated during incubation at $37^{\circ} \mathrm{C}$, indicating that the 293 cell extract had an activity capable of activating caspases.

\section{Caspase activation depends on expression of the E1A} oncogene

Although only a few cell lines have been tested, apoptosis in mammalian cell-free systems previously has re-

Figure 2. Extracts from untreated 293 cells induce apoptosis and caspase activation in a cell-free system. (A) 293 extracts induce nuclear changes of apoptosis in a cell-free system. 293 cell extract $(10 \mu l)$ was incubated with isolated HeLa nuclei $\left(1 \times 10^{5}\right)$ for $60 \mathrm{~min}$ at $37^{\circ} \mathrm{C}$. Another aliquot was incubated with nuclei under the same conditions but biotin-YVAD-amk $(100 \mu \mathrm{M})$, an inhibitor of caspases, was added. After incubation, nuclei were fixed and stained with DAPI, they were examined by fluorescence microscopy for apoptotic changes. Virtually all nuclei underwent apoptotic changes in the 293 extract. No nuclei displayed apoptotic morphology in the extract containing biotin-YVADamk. The nuclei shown are representative of each treatment. $(B-D)$ Caspases are activated in extracts from 293 cells. 293 cell extracts were incubated at $37^{\circ} \mathrm{C}$ and at the indicated times activation of caspases in the extracts was assessed by three assays. (B) caspase activity as measured by the amount of DEVD-afc, a fluorogenic

A
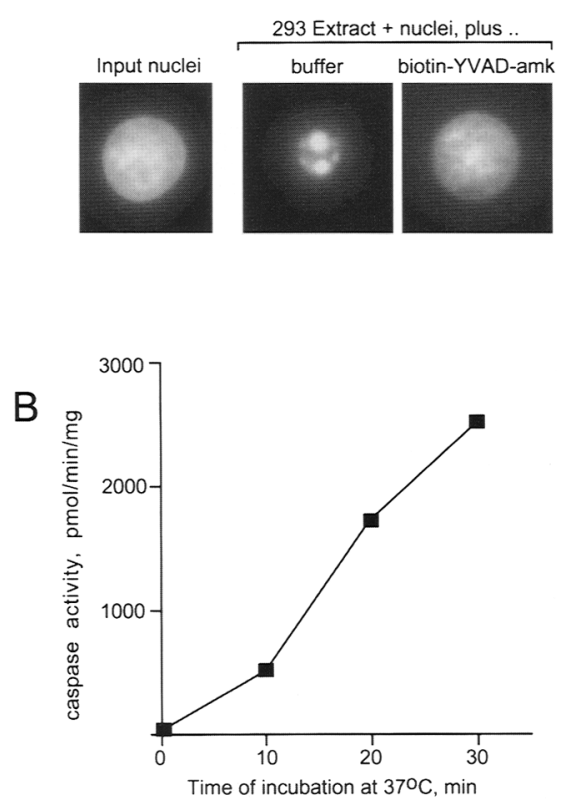

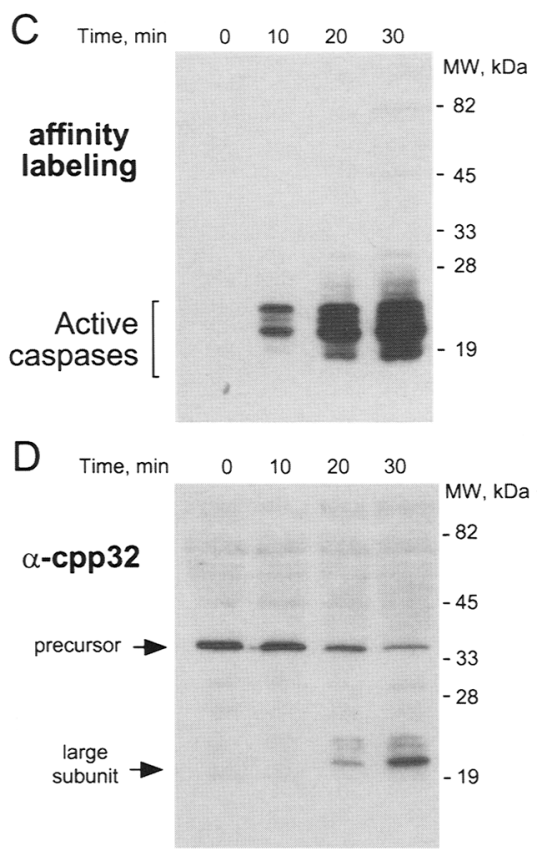

caspase substrate, cleaved by the extracts (Nicholson et al. 1995). Activity is expressed in picomoles of free afc released by milligram of total extract protein per minute at $30^{\circ} \mathrm{C}$. Activity of extract before incubation was 17 pmoles $/ \mathrm{min}$ per mg. (C) Activation of caspases as revealed by affinity-labeling with biotin-YVAD-amk $(10 \mu \mathrm{M}) ;(D)$ processing of CPP32, a caspase implicated in apoptosis, as revealed by immunoblotting with an anti-CPP32 antibody. The antibody used detects the CPP32 precursor and the large subunit of the active enzyme. The results presented in $B-D$ are from the same experiment. The same blot was used to visualize affinity labeled caspases $|C|$ and the processed forms of CPP32 $(D)$. 
quired extracts from cells undergoing apoptosis (Lazebnik et al. 1993; Enari et al. 1995; Martin et al. 1995/. 293 cells are different from cell lines used previously in that they express the adenovirus E1A and E1B oncogenes. Because E1A expression can induce apoptosis (White 1993), it was possible that activation of caspases in the 293 cell extract resulted directly or indirectly from the expression of E1A. To test this hypothesis, we used primary MEFs and their E1A-expressing derivatives. This model has been used extensively to study E1A and E1B function in transformation and apoptosis (Lowe et al. 1993, 1994). Furthermore, this model allowed analysis of the specific effects of these oncogenes in primary cells without interference from secondary genetic changes.

MEFs expressing E1A alone are highly prone to apoptosis (Lowe et al. 1993; Boulakia et al. 1996; McCurrach et al. 1997). Consistent with this effect, extracts from these cells induced apoptosis in vitro (Fig. 3A) and activated caspases (Fig. $3 \mathrm{~B}$ ) upon incubation at $37^{\circ} \mathrm{C}$ but not $4^{\circ} \mathrm{C}$. In contrast to extracts from cells expressing ElA, extracts from normal MEFs (Fig. 3) or MEFs containing the vector alone (data not shown) failed to induce apoptosis in the cell-free system and did not activate caspases (Fig. 3A,B). Thus, caspase activation in the extracts depended on expression of E1A.

It was possible that untransformed MEFs fail to acti- vate caspases because they lacked either the caspase-activating activity or the caspases themselves. To test whether extracts from untransformed cells had caspase precursors, we added recombinant ICE, a caspase that can activate other caspases in vitro (Xue et al. 1996). As revealed by affinity labeling, endogenous caspases were activated by addition of ICE (Fig. 3C). To confirm this result, we used the observation that dATP activates CPP32 in cell extracts (Liu et al. 1996). Indeed, addition of dATP to extracts from untransformed cells activated caspases, as measured by the fluorogenic assay. Furthermore, the amount of latent caspase activity revealed in extracts from untransformed MEFs was comparable to that spontaneously activated in extracts from either E1A/E1B transformed MEFs or 293 cells. Thus, the extract from normal MEFs contained inactive caspases, but lacked the ElA-generated activity capable of activating them. We will refer to this activity as the oncogenegenerated activity (OGA).

Unlike $\bar{M}$ EFs expressing E1 A alone, MEFs transformed by E1A and E1B are highly resistant to drug-induced apoptosis (Lowe et al. 1993; Subramanian et al. 1993). However, extracts from MEFs expressing E1A and E1B induced apoptosis in vitro (Fig. 3A) and activated caspases (Fig. 3B), as did extracts from MEFs expressing E1A. Similar results were obtained when E1B was sub-

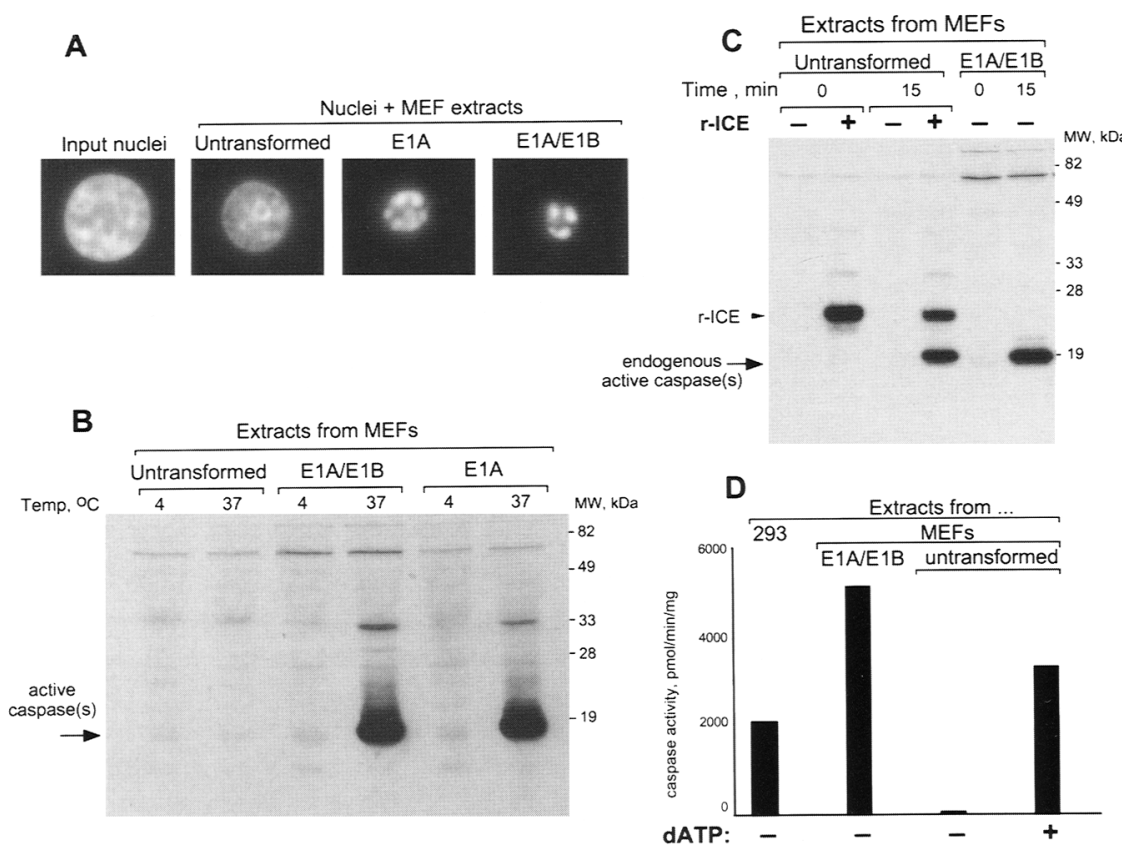

Figure 3. Extracts from MEFs expressing E1A or E1A plus E1B, but not from untransformed MEFs, induce apoptosis and caspase activation in a cell-free system. (A) Extracts induce nuclear changes of apoptosis in a cell-free system. Extracts $(10 \mu 1)$ were incubated with HeLa nuclei $\left(1 \times 10^{5}\right)$ for $60 \mathrm{~min}$ at $37^{\circ} \mathrm{C}$. After incubation, nuclei were stained with DAPI and examined by fluorescence microscopy for apoptotic changes. Virtually all nuclei underwent apoptotic changes in extracts from MEFs expressing E1A or E1A plus E1B. No nuclei displayed apoptotic morphology in extracts from untransformed MEFs. The nuclei shown are representative of each treatment. (B) Activation of caspases as revealed by affinitylabeling with biotin-YVAD-amk $(10 \mu \mathrm{M})$. Extracts were incubated for $60 \mathrm{~min}$ at $37^{\circ} \mathrm{C}$ and active caspases were labeled as described in Materials and Methods. Activation of caspases was confirmed using a fluorogenic substrate, DEVD-afc (data not shown). Before incubation at $37^{\circ} \mathrm{C}$ all $\mathrm{MEF}$ extracts had caspase activity $<15$ pmoles/ min per mg. After incubation, extracts from untransformed MEF had activity of 3 pmoles $/ \mathrm{min}$ per mg whereas extracts from E1A alone and El A plus E1B MEF had activity of 2300 and 5200 pmoles/min per mg, respectively. $(C, D)$ Extracts from untransformed MEFs have caspase precursors but fail to activate them. (C) Recombinant ICE activates caspase precursors in the extract from untransformed MEFs. The extract $(10 \mu \mathrm{l})$ was incubated for $15 \mathrm{~min}$ at $37^{\circ} \mathrm{C}$ with or without recombinant ICE (15 ng). Extracts from E1A/E1B MEF $(10 \mu \mathrm{l})$ containing active caspases were used as a positive control. Active caspases in all extracts were labeled with biotin-YVAD-amk $(10 \mu \mathrm{M})$ and visualized as described in Materials and Methods. (D) Activation of caspase precursors by dATP as measured by the cleavage of DEVD-afc, a caspase substrate. The extract from untransformed MEFs was incubated for 1 hr with or without $2 \mathrm{mM}$ dATP. Extracts from E1A/E1B transformed MEFs and from 293 cells were used for comparison. The results are typical of two independent experiments. 
stituted with the antiapoptotic oncogene $b c 12$ (data not shown). Thus OGA was latent in these cells and was revealed in cell extracts.

\section{E1B-19K and Bcl-2 are absent in cell extracts}

Although E1B-19K (an antiapoptotic protein encoded by the $\mathrm{E} 1 \mathrm{~B}$ gene) and $\mathrm{Bcl} 2$ are potent inhibitors of apoptosis in whole cells, extracts from cells expressing either protein readily activated caspases in vitro. To investigate why E1B failed to inhibit caspase activation in extracts, we determined whether E1B-19K was present in extracts. Consistent with previous reports (White et al. 1984), E1B-19K partitioned with insoluble material during centrifugation and was absent in extracts from either 293 cells or E1A/E1B expressing MEFs (Fig. 4). Similarly, when $\mathrm{Bcl} 2$ was coexpressed with E1A, it also partitioned with insoluble material during extract preparation (data not shown). Thus, the absence of $\mathrm{E} 1 \mathrm{~B}-19 \mathrm{~K}$ and $\mathrm{Bcl} 2$ from cell extracts may explain why caspase activation was not inhibited in vitro.

We attempted to reintroduce $\mathrm{E} 1 \mathrm{~B}-19 \mathrm{~K}$ and $\mathrm{Bcl} 2$ to the extracts. Reintroduction of E1B-19K was not feasible because of its poor solubility. Recombinant Bcl 2 made soluble by removal of the membrane anchoring domain (Hockenbery et al. 1993) had no effect on caspase activation (data not shown). Whether caspase activation in cell extracts is beyond Bcl 2 control, or whether the recombinant $\mathrm{Bcl} 2$ is impaired, remains to be investigated.

\section{OGA requires ATP hydrolysis}

As the first step in the characterization of OGA, we determined its thermostability. Caspases in the 293 extract were activated at $30^{\circ} \mathrm{C}$ and $37^{\circ} \mathrm{C}$, but remained inactive at room temperature or when kept on ice (Fig. 5A). Incubation of extracts at $45^{\circ} \mathrm{C}$ prevented caspase activation although had no effect on activated caspases. We also investigated the ion requirement of OGA. Because the extracts contain $5 \mathrm{~mm}$ EGTA, OGA is unlikely to require calcium and other ions that bind to this chelator. However, OGA, but not activated caspases, required magne-

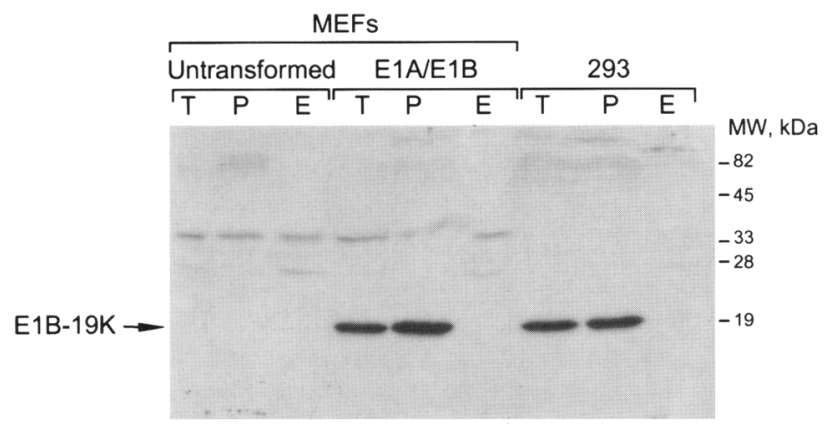

Figure 4. E1B-19K is depleted from cell extracts during extract preparation. For each cell type, an aliquot of total cell lysate was loaded in lane $T$. An equal aliquot was separated by centrifugation at $100,000 \mathrm{~g}$ for $1 \mathrm{hr}$ to obtain pellet $(\mathrm{P})$ and extract $(\mathrm{E})$. The results are typical of two independent experiments. sium, as determined by adding EDTA or by dialysis (data not shown).

Although caspases in the extract were activated spontaneously, we noticed that addition of an ATP-regeneration system increased the rate of activation two- to threefold, but did not have an effect on activated caspases (data not shown). The dependence on ATP and magnesium suggested that OGA requires ATP hydrolysis. 293 extract dialyzed to remove both ATP and magnesium did not activate caspases, but OGA was restored by addition of both ATP and magnesium (either alone was insufficient) (Fig. 5B). ADP supported caspase activation in the presence of magnesium but was much less efficient than ATP even at concentrations 10 times that of ATP (Fig. 5B; data not shown). AMP, adenosine, and GTP failed to promote caspase activation (Fig. 5B; data not shown). The nonhydrolysable ATP analogs, ATP- $\gamma$-S and AMP-PNP, did not substitute for ATP, indicating that ATP hydrolysis was required (Fig. 5C). Hence, OGA required hydrolysis of ATP to activate caspases.

\section{OGA can be separated from its targets by chromatography}

Having established dependence of OGA on ATP, we partially purified this activity by ion-exchange chromatography. We fractionated the 293 extract on a Sepharose Q column into a flowthrough (FT), a $100 \mathrm{~mm} \mathrm{KCl}$ eluate (fraction 1), and a $450 \mathrm{~mm}$ eluate (fraction 2). FT and fraction 2 contained $\sim 48 \%$ each of all recovered protein with $3 \%-4 \%$ eluted in fraction 1 . None of the fractions had caspase activity and no caspases were activated by incubation at $37^{\circ} \mathrm{C}$, as measured by the fluorogenic assay (Fig. 6A) or affinity labeling (Fig. 6B). However, caspase activation was reconstituted by combining the FT with fraction 1 but not with fraction 2. Affinity labeling with biotin-YVAD-amk confirmed these observations (Fig. 6B). Consistent with our finding that OGA requires ATP, combining FT with fraction 1 resulted in caspase activation only in the presence of ATP (Fig. 6C).

Although no fraction alone had active caspases, caspase precursors could be present in any fraction. Therefore, to activate precursors, should they be present, we added recombinant ICE to each fraction and then quantified caspase activity using DEVD-afc, a fluorogenic substrate not cleaved by ICE. Although caspase activity was revealed in all fractions, $90 \%$ of the activity was present in the $\mathrm{FT}, 7 \%$ in fraction 1 , and $3 \%$ in fraction 2 (Fig. 6D). Affinity labeling with biotin-YVADamk revealed a similar distribution (data not shown) and immunoblotting for CPP32 revealed that this caspase was present only in the FT (data not shown). Hence, OGA and its targets were distributed between FT and fraction 1 .

\section{OGA from 293 cells activates caspases in extracts from untransformed MEFs}

It is possible that OGA is present only in the FT or only in fraction 1, but we require target caspases in the other fraction to detect it. Alternatively, OGA may consist of 
A

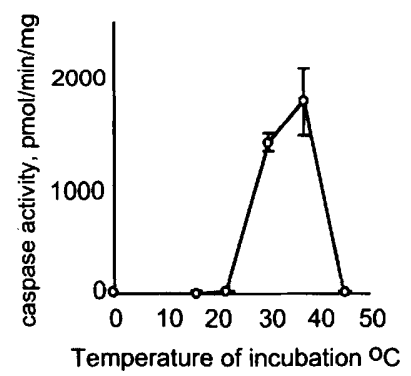

B

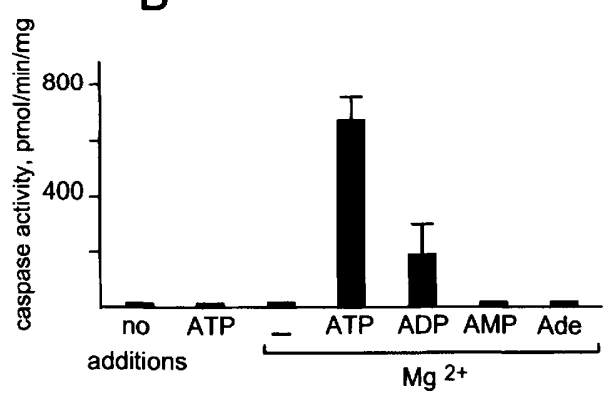

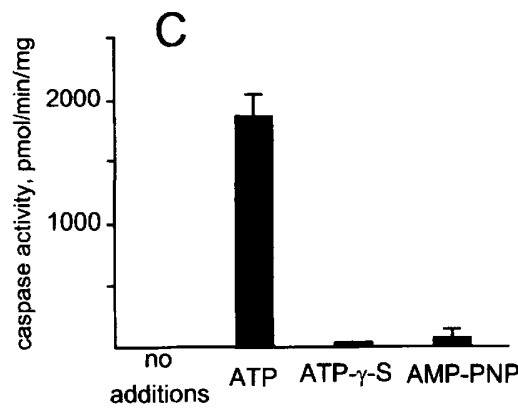

Figure 5. The ElA-generated activity that processes caspases is thermolabile and requires ATP hydrolysis. Caspase activity was measured by cleavage of DEVD-afc and expressed in pmoles of free afc released by milligram of total extract protein per minute at $30^{\circ} \mathrm{C}$. $(A)$ Temperature sensitivity of caspase activation. 293 cell extracts were incubated at the indicated temperatures for 60 min and caspase activity was then measured. (B) Caspase activation requires ATP and magnesium. 293 cell extracts were dialyzed overnight using a $10-\mathrm{kD}$ cutoff membrane and a buffer lacking magnesium. Extracts were supplemented as indicated, incubated for 15 min at $37^{\circ} \mathrm{C}$ and caspase activity then measured. (Ade) Adenosine. (C) Caspase activation requires ATP hydrolysis. 293 cell extracts dialyzed against a buffer lacking magnesium were supplemented with $1 \mathrm{mM} \mathrm{MgCl}_{2}$ and either ATP (1 $\mathrm{mM}$ ) or nonhydrolysable ATP analogs (1 $\mathrm{mM}$ ). Extracts were incubated at $37^{\circ} \mathrm{C}$ for $60 \mathrm{~min}$ and caspase activity was measured. Three independent preparations of 293 cell extracts were used for each experiment.

components distributed between fraction 1 and FT. To distinguish between these possibilities, we added the fractions to extracts from normal MEFs, which contain caspase precursors but lack the activating signal (see Fig. $3 \mathrm{C}, \mathrm{D})$. Remarkably, the addition of fraction 1 but not fraction 2 or FT activated caspases in MEF extracts (Fig. $7 \mathrm{~A}, \mathrm{~B})$. Two pieces of evidence suggest that adding fraction 1 to extracts from untransformed cells results in activation of MEF caspases. First, caspases activated had electrophoretic mobility similar to those of caspases activated in extracts from E1A/E1B-transformed MEFs. Second, fraction 1 had no detectable caspase activity and adding recombinant ICE to fraction 1 revealed only a small amount of caspase precursors, which cannot account for the dramatic increase of caspase activity in the MEF extract (Fig. 6D). Finally, the activation factor in
A

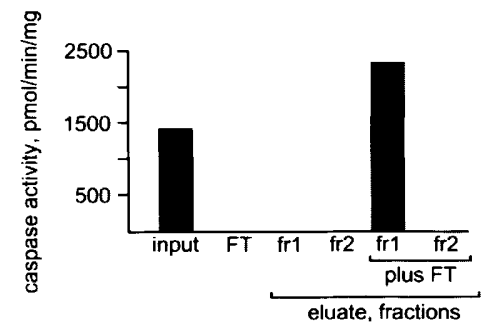

C

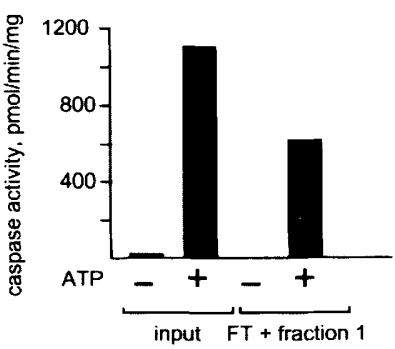

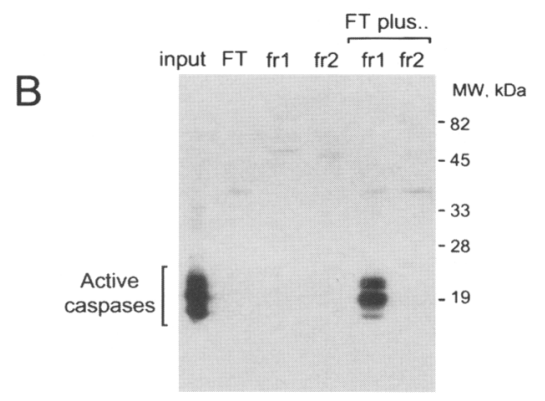

D

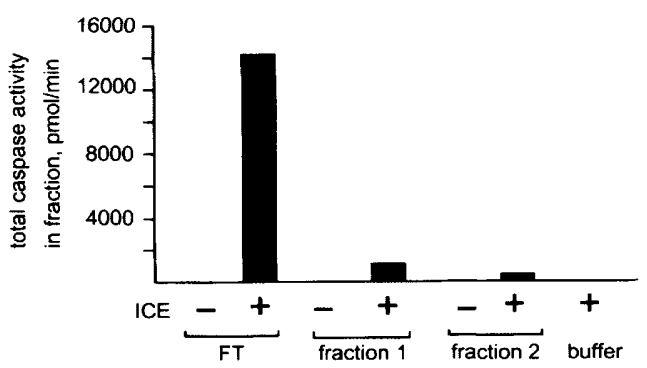

Figure 6. $(A, B)$ Combination of fractions lacking caspase activity reconstitute caspase activation. 293 cell extract was fractionated by anion exchange chromatography into the flow through (FT), fraction 1 , and fraction 2. FT $(40 \mu \mathrm{g})$ was combined with either fraction $1(6 \mu \mathrm{g})$ or fraction $2(6 \mu \mathrm{g})$, supplemented with $1 \mathrm{~mm}$ ATP and incubate for $15 \mathrm{~min}$ at $37^{\circ} \mathrm{C}$. Active caspases were then detected by using either fluorogenic substrate DEVD-afc $(A)$ or affinity labeling with biotin-YVADamk $(10 \mu \mathrm{M})(B) .(C)$ Reconstituted caspase activation is ATP-dependent. Input extract or a mixture of FT $(40 \mu \mathrm{g})$ and fraction $1(6 \mu \mathrm{g})$ was incubated for $15 \mathrm{~min}$ at $37^{\circ} \mathrm{C}$ with or without $1 \mathrm{mM} \mathrm{ATP}$, and caspase activity was measured using the caspase substrate DEVD-afc. $(D)$ Caspase precursors are present in all fractions. FT, fraction 1 , and fraction 2 were incubated for $15 \mathrm{~min}$ at $37^{\circ} \mathrm{C}$ with or without $15 \mathrm{ng}$ of active recombinant ICE. Caspase activity was then measured using DEVD-afc. To show the relative amount of caspase precursors the results are presented as total activity in each fraction. The fractionation and reconstitution shown is typical of four independent experiments. 
fraction 1 displayed a similar ATP dependence as shown for OGA in whole 293 extracts. Hence, fraction 1 contains partially purified OGA that is able to biochemically reproduce the proapoptotic effect of ElA expression on caspase activation.

As OGA required E1A expression, OGA could be E1A itself. Therefore, using immunoblotting we tested whether E1A is present in fraction 1 and found that it is not (Fig. 7D). OGA could also be cytochrome $c$, a protein required for CPP32 activation in a cell-free system (Liu et al. 1996). However, cytochrome $c$ was not detectable by immunoblotting in fraction 1 (Fig. 7D).

Thus, this study provides biochemical evidence that expression of an oncogene generates a proapoptotic activity (OGA) that persists even when cells acquire drug resistance. The assays for OGA developed here should facilitate identification of this activity.

\section{Discussion}

Many oncogenes that promote cell proliferation also induce apoptosis (Harrington et al. 1994), indicating that transformation by these oncogenes requires suppression of cell death. However, whether the proapoptotic activity generated by oncogenes persists in transformed cells was not known. Here we used cells expressing the proapoptotic oncogene ElA and the antiapoptotic oncogene E1B as a model of cell transformation. Employing extracts from these cells in a cell-free system of apoptosis we provide evidence that the proapoptotic activity generated by E1A (OGA) persists in transformed cells, even when they acquire resistance to apoptosis through expression of E1B. We suggest that because OGA is generated by an oncogene and is absent from untransformed cells, this activity may be exploited to selectively kill transformed cells.

The dependence of apoptosis on caspase activity indicates that the activation of caspases is the critical step in cell death. Although it is well established that the expression of many oncogenes induces apoptosis (Evan et al. 1992; Rao et al. 1992; Howes et al. 1994; Yamada et al. 1994; Galaktionov et al. 1996; Sala et al. 1996), how oncogene expression activates caspases is not known. In principle, E1A expression may induce caspase activation by the removal of an inhibitor that prevents this activation in normal cells or by the generation of a factor that activates caspases. Several of our observations suggest that the latter possibility is more likely. First, caspase activation is prevented by extract fractionation, indicating that caspases cannot activate themselves. Second, this activation can be reconstituted by combining the fractions, indicating that the fractionation separates caspases from an activator. Third, this activator induces caspase activation in the extracts from untransformed cells. Thus, the expression of E1A generates an activity, which we termed OGA, that drives caspase activation.

Although OGA remains to be identified, it is very likely to be protein or protein complex because of its
Figure 7. OGA induces caspase activation when added to extracts from untransformed MEFs. $(A, B)$ Fraction 1, but not FT or fraction 2 , induces caspase activation when added to extracts from untransformed MEFs. Extracts from untransformed MEFs $(160 \mu \mathrm{g})$ were incubated for $15 \mathrm{~min}$ at $37^{\circ} \mathrm{C}$ with $\mathrm{FT}(33 \mu \mathrm{g})$, fraction 1 $(33 \mu \mathrm{g})$, or fraction $2(33 \mu \mathrm{g})$ in the presence of $1 \mathrm{~mm}$ ATP. Caspase activity was then measured using DEVD-afc $(A)$ or by affinity labeling with YVAD-amk $(10 \mu M)(B)$. $(C)$ Caspase activation triggered by fraction 1 requires ATP. Extracts from untransformed MEFs were dialyzed to remove endogenous ATP. Dialyzed extract alone $(160 \mu \mathrm{g})$ or plus fraction $1(33 \mu \mathrm{g})$ was incubated for $15 \mathrm{~min}$ at $37^{\circ} \mathrm{C}$ with or without $1 \mathrm{mM}$ ATP. Caspase activity was then measured using DEVD-afc. The results are typical of two independent experiments. (D) Immunoblotting reveals that fraction 1 does not contain cytochrome $c$ or E1A. Extracts from 293 cells (input) were fractionated by anion exchange chromatography (see Fig. 6) into FT, fraction 1, and fraction 2. An equal amount of protein from each fraction $(10 \mu \mathrm{g})$ was loaded in each lane. The blot was first probed using an antibody to cytochrome $c$ and then stripped and probed with an antibody to E1A.
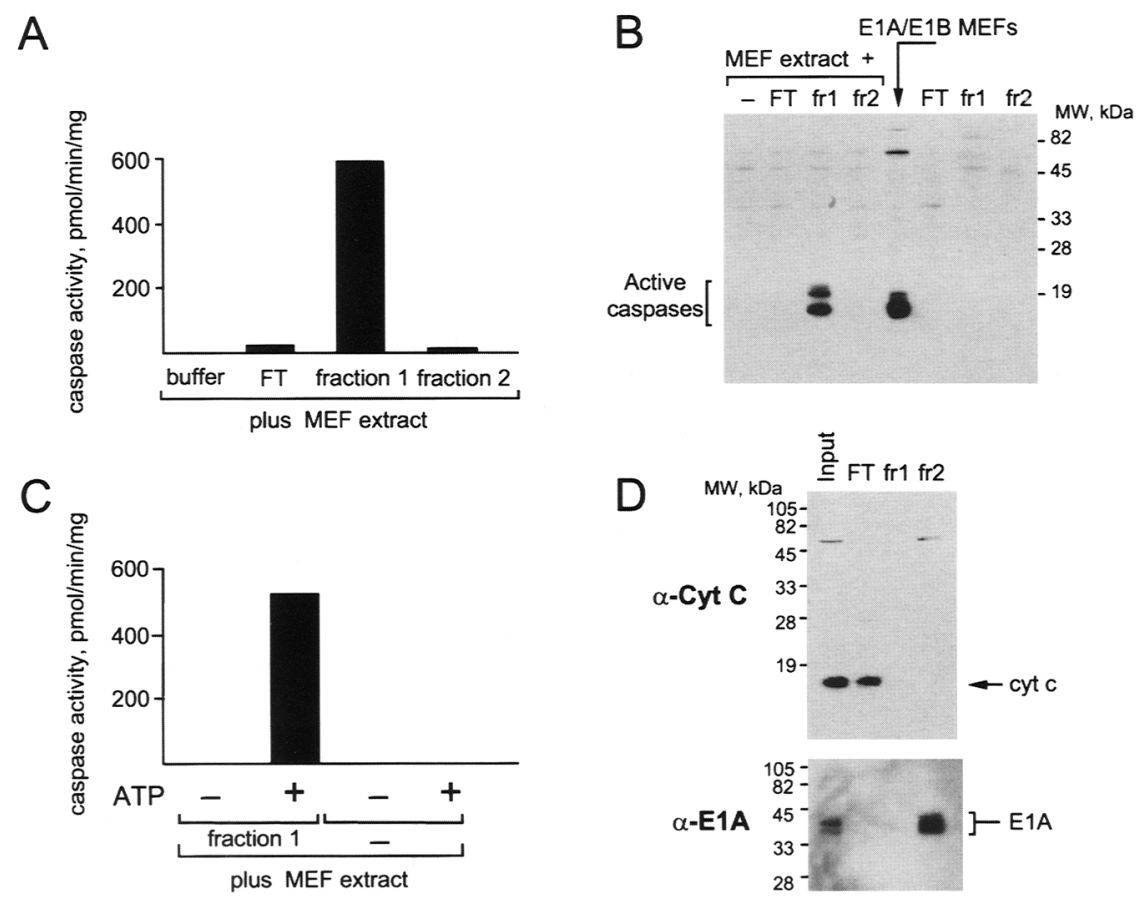
behavior during chromatography and dialysis, its thermolability, and its requirement for ATP hydrolysis. Although we cannot rule out that OGA is a caspase, this is unlikely because the activity of known caspases does not require ATP hydrolysis and no caspase activity was detected in partially purified OGA. Because OGA could be generated by the expression of a single gene, E1A, then in principle OGA could be E1A itself. However, E1A is absent from partially purified OGA (fraction 1), showing that OGA is not ElA. Hence, it is likely that ElA expression activates caspases indirectly by inducing OGA.

How caspases are activated by OGA, or by any other apoptotic stimulus, is not known. Recent studies suggest two possible mechanisms, both involving Bcl2-controlled-release of proteins that activate caspases from mitochondria. One of these proteins is cytochrome $c$ (Kluck et al. 1997; Yang et al. 1997) and the other is apoptosis inducing factor (AIF) (Susin et al. 1996; Zamzami et al. 1996), which is yet to be characterized. Because our extract preparation is likely to result in the release of mitochondrial contents, either cytochrome $c$ or AIF could be OGA. However, several observations argue that OGA is neither. First, both cytochrome $c$ and AIF (Susin et al. 1996) are present in normal cells, whereas OGA is not. Second, as detected by immunoblotting, all extracts contained comparable amounts of cytochrome $c$ (data not shown), whereas only extracts from transformed cells activated caspases. Although we could not measure AIF in the extracts, comparable amounts of cytochrome $c$ suggested that other mitochondrial contents were also released equally during preparation of all extracts. Thus, the release of mitochondrial contents alone is unlikely to explain caspase activation. Third, cytochrome $c$ was not detected in partially purified OGA (fraction 1). Finally, neither cytochrome $c$ nor AIF require ATP hydrolysis, whereas OGA does. Hence, OGA is not cytochrome $c$ and is unlikely to be AIF, although the identification of AIF and OGA will provide an unambiguous answer.

The observation that OGA requires ATP hydrolysis suggests several possible mechanisms of caspase activation. One is that an ATP-dependent protease directly processes caspases. Our observation that fraction 1 does not process recombinant CPP32 (data not shown) argues that this is not the case. Another possibility is that phosphorylation of caspases changes caspase conformation and induces autocatalytic processing. ATP-dependent conformational changes in caspases may also be induced by chaperones, proteins whose expression is increased by E1A (Nevin 1982). The finding that dATP or dADP can activate CPP32 in cell extracts (Liu et al. 1996) and our observation that dATP can activate caspases in extracts from untransformed cells suggests a third possibility: OGA requires ATP to generate dATP or dADP. In untransformed cells, the pool of dNTPs is controlled by ribonucleotide reductase (RNR), whose expression is tightly regulated in the cell cycle (Elledge et al. 1992). This regulation is lost in transformed cells (Hengstschlager et al. 1994). Thus it is possible that deregulation of the cell cycle forced by E1A expression is linked to caspase activation through dATP. However, we found that hydroxyurea, an inhibitor of RNR, failed to block activation of caspases in the 293 cell extract (data not shown). Nevertheless, dATP might be produced by another reductase insensitive to hydroxyurea. Identification of OGA should determine what role ATP has in caspase activation.

Although cells expressing E1A alone are susceptible to apoptosis, coexpression of $\mathrm{E} 1 \mathrm{~B}$ or $\mathrm{Bcl} 2$ renders them highly resistant to apoptosis-inducing agents. Nonetheless, we show that irrespective of their sensitivity to apoptosis, extracts from E1A-expressing cells activate caspases. Thus, a reasonable interpretation is that OGA generated by ElA is latent in resistant cells but is revealed by extract preparation. This latency may be explained if OGA is sequestered by Bcl2-like proteins in cells but is released during extract preparation. This is consistent with our observation that both these proteins are segregated with the insoluble fraction during extract preparation and are not detectable in the extracts. One possibility is that Bcl2 homologs sequester OGA by directly binding to it. This is consistent with the model that E1B-19K and Bcl2 bind activators of apoptosis such as Bad and Bax (Oltvai et al. 1993; Yang et al. 1995). Bax itself is unlikely to be OGA because expression of $\mathrm{Bax}$ kills E1A/E1B-transformed fibroblasts but has little effect on untransformed cells (McCurrach et al. 1997). The selectivity of Bax killing can be explained if Bax releases OGA from a protein-like E1B-19K. Another explanation of why OGA is revealed in cell extracts is that in cells, OGA is sequestered in subcellular compartments that are disrupted by extract preparation. This model implies that in cells, the release of OGA is controlled by Bcl2like proteins.

Whatever OGA is, it is generated by the expression of an oncogene and persists in cells that acquired drug resistance. Thus, exploiting OGA may provide a basis for selective activation of apoptotic caspases in transformed cells, even those that are resistant to conventional therapy. It is likely that the OGA is not limited to cells expressing E1A because E1A is only one of many oncogenes that have proapoptotic activity (Evan et al. 1992; Howes et al. 1994; Yamada et al. 1994; Galaktionov et al. 1996; Sala et al. 1996). Consistent with this prediction, we detected spontaneous activation of caspases in extracts from HeLa cells, a human cervical carcinoma cell line expressing proapoptotic papillomavirus oncogene $\mathrm{E} 7$ (data not shown). However, even if OGA is limited to a few experimental models, identification of this activity should provide a link between oncogene expression and the apoptotic machinery that may be exploited to induce apoptosis in transformed cells.

\section{Materials and methods}

Cell culture

293 cells were maintained in suspension at $37^{\circ} \mathrm{C}$ in Joklik modified minimum essential medium supplemented with $5 \%$ calf serum. Jurkat cells were maintained in suspension at $37^{\circ} \mathrm{C}$ in RPMI-1640 supplemented with $10 \%$ fetal bovine serum. Trans- 
formed and untransformed MEFs were maintained at $37^{\circ} \mathrm{C}$ and $7.5 \% \mathrm{CO}_{2}$ in Dulbecco's modified Eagle medium (DMEM) supplemented with $10 \%$ calf serum.

\section{MEF transformation and infection}

Preparation of primary MEFs and their derivatives transformed by adenovirus- 5 E1A and E1B have been described previously (Lowe et al. 1994). Extracts from normal MEFs were prepared at or before passage 5. MEFs expressing E1 A alone were generated by infection of second-passage MEFs with a high-titer retroviral vector coexpressing a $12 \mathrm{~S}$ E1A cDNA with puromycin phosphotransferase as described elsewhere (McCurrach et al. 1997). Cells were expanded minimally (approximately four additional passages) to avoid the occurrence of secondary genetic changes.

\section{Extract preparation}

Extracts were prepared essentially as described (Lazebnik et al. 1993). 293 cells $\left(5 \times 10^{5}\right.$ to $7 \times 10^{5}$ cells $\left./ \mathrm{ml}\right)$ were washed and the pellet was gently resuspended in 10 volumes of extract preparation buffer $(50 \mathrm{~mm}$ PIPES at $\mathrm{pH} 7.0,50 \mathrm{mM} \mathrm{KCl}, 5 \mathrm{~mm}$ EGTA, $2 \mathrm{mM} \mathrm{MgCl}_{2}$, $1 \mathrm{~mm}$ DTT) supplemented with $10 \mu \mathrm{g} / \mathrm{ml}$ of cytochalasin $B$ and protease inhibitor cocktail $10.1 \mathrm{~mm}$ PMSF and $2 \mu \mathrm{g} / \mathrm{ml}$ each of chymostatin, pepstatin, leupeptin, and antipain). Cells were immediately pelleted ( $200 \mathrm{~g}$ for $5 \mathrm{~min}$ ) and lysed by three cycles of freezing and thawing. The lysate was centrifuged at $100,000 \mathrm{~g}$ for $1 \mathrm{hr}$ to produce the cell extract. Extracts from MEFs were prepared by the same protocol except MEFs were first detached from plates with trypsin and washed with medium containing $50 \%$ fetal bovine serum to inactivate trypsin.

\section{Nuclei preparation}

HeLa or 293 nuclei were prepared as described (Lazebnik et al. 1993|. Briefly, HeLa or 293 cells were allowed to swell on ice for $20 \mathrm{~min}$ in the nuclei buffer (10 mM PIPES at $\mathrm{pH} 7.4,10 \mathrm{~mm} \mathrm{KCl}$, $1.5 \mathrm{mM} \mathrm{MgCl}_{2}, 1 \mathrm{~mm} \mathrm{DTT}, 10 \mu \mathrm{g} / \mathrm{ml}$ of cytochalasin $\mathrm{B}$, and the protease inhibitor cocktail) and then gently lysed with a Dounce homogenizer. The nuclei were pelleted through the nuclei buffer supplemented with $30 \%$ sucrose, washed in nuclei buffer, and either used or stored at $-20^{\circ} \mathrm{C}$ in nuclei storage buffer $(10$ mM PIPES at $\mathrm{pH} 7.4,80 \mathrm{~mm} \mathrm{KCl}, 20 \mathrm{~mm} \mathrm{NaCl}, 250 \mathrm{~mm}$ sucrose, $5 \mathrm{~mm}$ EGTA, $1 \mathrm{~mm}$ DTT, $0.5 \mathrm{~mm}$ spermidine, $0.2 \mathrm{~mm}$ spermine, the protease inhibitor cocktail, and $50 \%$ glycerol) at $1 \times 10^{8} \mathrm{nu}-$ $\mathrm{clei} / \mathrm{ml}$. Nuclei were washed twice in extract dilution buffer (DB) (10 mM HEPES at $\mathrm{pH} 7.0,50 \mathrm{~mm} \mathrm{NaCl}, 2 \mathrm{mM} \mathrm{MgCl} 2,5 \mathrm{~mm}$ EGTA, $1 \mathrm{mM}$ DTT) immediately before use.

\section{Cell-free system}

The cell-free assays were similar to that described previously (Lazebnik et al. 1993). Purified nuclei $\left(5 \times 10^{5}\right\}$ were added to an extract $(10 \mu \mathrm{l})$ supplemented with an ATP regeneration system $12 \mathrm{mM}$ ATP, $10 \mathrm{~mm}$ creatine phosphate, and $50 \mu \mathrm{g} / \mathrm{ml}$ of creatine kinasel. The reaction was incubated for $60 \mathrm{~min}$ at $37^{\circ} \mathrm{C}$. To observe nuclear apoptotic changes, nuclei were fixed with $4 \%$ paraformaldehyde, stained with DAPI $(1 \mu \mathrm{g} / \mathrm{ml})$, and examined by fluorescence microscopy. Images were acquired using a Photometrics PXL CCD camera (Photometrics Ltd.) controlled by Oncor Image software (Oncor Inc.) and figures were prepared using Adobe Photoshop software.

\section{Measuring caspase activity using a fluorogenic substrate}

Caspase activity was measured essentially as described (Thornberry 1994). Two hundred microliters of assay buffer $(50 \mathrm{mM}$ PIPES-potassium hydroxide at $\mathrm{pH} 7.0,0.1 \mathrm{~mm}$ EDTA, $1 \mathrm{~mm}$ DTT, $10 \%$ glycerol) containing the fluorescent substrate DEVD-afc $(20 \mu \mathrm{M})$ (Enzyme Systems Products) was incubated with $1 \mu \mathrm{l}$ of extract for $20 \mathrm{~min}$ at $30^{\circ} \mathrm{C}$. The release of free afc was measured with a fluorescence plate reader, Cytofluor 4000 (Perseptive Biosystems), and expressed as pmoles of afc generated per minute per milligram of the total extract protein at $30^{\circ} \mathrm{C}$.

\section{Affinity labeling of active caspases}

The caspase affinity probe biotin-YVAD-amk (Thornberry et al. 1994) (Biosyn, Ireland) was prepared as a $10 \mathrm{~mm}$ stock solution in DMSO, which was aliquoted and stored at $-70^{\circ} \mathrm{C}$. Immediately before use aliquots were diluted to either 20 or $10 \mu \mathrm{M}$ with DB buffer.

Labeling of cells Cells were labeled essentially as described (Faleiro et al. 1997). Cells $\left(2 \times 10^{6}\right)$ were resuspended in $10 \mu \mathrm{M}$ biotin-YVAD-amk in DB (10 $\mu 1)$ supplemented with the protease inhibitor cocktail and $10 \mu \mathrm{g} / \mathrm{ml}$ of cytochalasin $\mathrm{B}$, and lysed by three cycles of freezing and thawing. The lysate was centrifuged $\left(16,000 \mathrm{~g}, 20 \mathrm{~min}, 4^{\circ} \mathrm{C}\right)$ and the supernatant incubated at $37^{\circ} \mathrm{C}$ for $4 \mathrm{~min}$ to label active caspases. This incubation was sufficient to achieve maximal caspase labeling (data not shown). Labeling was stopped by adding $2 \times$ SDS sample buffer $(10 \mu l)$. The samples were boiled for $4 \mathrm{~min}$, cooled, subjected to $15 \%$ SDS-PAGE with $10 \mu \mathrm{g}$ of total protein loaded per lane, and transferred on to a PVDF membrane. The membrane was probed with $1 \mu \mathrm{g} / \mathrm{ml}$ of avidin followed by $50 \mathrm{ng} / \mathrm{ml}$ of biotin-peroxidase and labeled caspases visualized by ECL (Amersham Inc).

Labeling of extracts Extract (5 $\mu$ l) was supplemented with an equal volume of $20 \mu \mathrm{M}$ biotin-YVAD-amk in DB and incubated at $37^{\circ} \mathrm{C}$ for $4 \mathrm{~min}$. Labeling was stopped by adding $2 \times \operatorname{SDS}$ sample buffer $(10 \mu l)$ and boiling the samples for $4 \mathrm{~min}$. Labeled caspases were visualized as described for caspases labeled in cells.

\section{Detection of CPP32 processing}

After affinity-labeled caspases were visualized as described in the previous section, membranes were soaked in methanol for 5 min to inactivate horseradish peroxidase, dried, and probed with a monoclonal antibody to CPP32 (Transduction Laboratories) followed by incubation with a secondary antibody conjugated to horseradish peroxidase. The position of CPP32 on the blot was visualized by ECL (Amersham Inc).

\section{Fractionation of 293 cell extracts}

All steps were carried out at $4^{\circ} \mathrm{C}$. 293 cell extracts were diluted 1:5 with a buffer containing $50 \mathrm{~mm}$ PIPES at $\mathrm{pH} 7,5 \mathrm{~mm}$ EGTA, $1 \mathrm{mM} \mathrm{MgCl}, 1 \mathrm{mMDTT}$, and $0.1 \mathrm{~mm}$ PMSF. Extract (40 mg) was then bound in batch to $5 \mathrm{ml}$ of Sepharose-Q and a column poured. The column was washed first with a buffer containing $50 \mathrm{~mm}$ PIPES at $\mathrm{pH} 7,10 \mathrm{~mm} \mathrm{KCl}, 5 \mathrm{~mm}$ EGTA, $1 \mathrm{~mm} \mathrm{MgCl}_{2}, 1$ mM DTT, and $0.1 \mathrm{mM} \mathrm{PMSF}$, and fractions containing proteins pooled (FT). Proteins were then eluted with the same buffer containing $100 \mathrm{mM} \mathrm{KCl}$ (fraction 1) followed by the same buffer containing $450 \mathrm{~mm} \mathrm{KCl}$ (fraction 2). Eluted proteins were precipitated with polyethyleneglycol and resuspended in extract preparation buffer. 


\section{Detection of cytochrome $\mathrm{c}$ and $E 1 \mathrm{~A}$}

Sample buffer ( $2 \times$ SDS) was added to an equal volume of unfractionated 293 cell extracts or fractionated (FT, fraction 1, and fraction 2) extracts. The samples were boiled for $4 \mathrm{~min}$, cooled, and subjected to $15 \%$ SDS-PAGE with $10 \mu \mathrm{g}$ of total protein loaded per lane. Protein was transferred on to a PVDF membrane and the membrane was probed with an antibody to cytochrome $c$, which was visualized by enhanced chemiluminescence (ECL). The blot was then stripped and probed with an antibody to E1A, which was also visualized by ECL.

\section{Acknowledgments}

We thank Nancy Thornberry for the kind gift of recombinant ICE, Bruce Stillman for an anti-E1B-19K antibody, Lavina Faleiro for sharing her expertise in caspase labeling and identification, and Ron Jemmerson for providing an anti-cytochrome $c$ antibody. We also thank our colleagues at Cold Spring Harbor Laboratories for helpful comments and criticisms. This work was supported by National Institutes of Health grant CA 13106 25 to Y.A.L. and S.W.L. and a Seligson Fellowship to H.O.F. Y.A.L. is a Pew Scholar.

The publication costs of this article were defrayed in part by payment of page charges. This article must therefore be hereby marked "advertisement" in accordance with 18 USC section 1734 solely to indicate this fact.

\section{References}

Alnemri, E.S., D.J. Livingston, D.W. Nicholson, G. Salvesen, N.A. Thornberry, W.W. Wong, and J.Y. Yuan. 1996. Human ICE/CED-3 protease nomenclature. Cell 87: 171.

Boulakia, C.A., G. Chen, F.W. Ng., J.G. Teodoro, P.E. Branton, D.W. Nicholson, G.G. Poirier, and G.C. Shore. 1996. Bcl2 and adenovirus E1B 19kDa protein prevent E1A-induced processing of cpp32 and cleavage of poly(ADP-ribose)polymerase. Oncogene 12: 529-535.

Chinnaiyan, A.M. and V.M. Dixit. 1996. The cell-death machine. Curr. Biol. 6: 555-562.

Dive, C. and J.A. Hickman. 1991. Drug-target interactions: Only the first step in the commitment to a programmed cell death. Br. I. Cancer 64: 192-196.

Elledge, S.J., Z. Zhou, and J.B. Allen. 1992. Ribonucleotide reductase: Regulation, regulation, regulation. Trends Biochem. Sci. 17: 119-123.

Enari, M., A. Hase, and S. Nagata. 1995. Apoptosis by a cytosolic extract from Fas-activated cells. EMBO J. 14: 5201-5208.

Enari, M., R.V. Talanian, W.W. Wong, and S. Nagata. 1996. Sequential activation of ICE-like and CPP32-like proteases during Fas-mediated apoptosis. Nature 380: 723-726.

Evan, G., A.H. Wyllie, C.S. Gilbert, T.D. Littlewood, H. Land, M. Brooks, C.M. Waters, L.Z. Penn, and D.C. Hancock. 1992. Induction of apoptosis in fibroblasts by c-myc protein. Cell 69: 119-128.

Faleiro, L., R. Kobayashi, H.O. Fearnhead, and Y.A. Lazebnik. 1997. Multiple species of CPP32 and Mch2 are the major active caspases present in apoptotic cells. EMBO T. 16: 22712281.

Galaktionov, K., X. Chen, and D. Beach. 1996. Cdc25 cell-cycle phosphatase as a target of c-myc. Nature 382: 51 1-517.

Graham, F.L., J. Smiley, W.C. Russell, and R. Nairn. 1977. Characteristics of a human cell line transformed by DNA from human adenovirus type 5. J. Gen. Virol. 36: 59-74.
Hacker, G. and D.L. Vaux. 1995. A sticky business. Curr. Biol. 5: 622-624.

Harrington, E.A., A. Fanidi, and G.I. Evan. 1994. Oncogenes and cell death. Curr. Opin. Genet. Dev. 4: 120-129.

Hengstschlager, M., I. Mudrak, E. Wintersberger, and E. Wawra. 1994. A common regulation of genes encoding enzymes of the deoxynucleotide metabolism is lost after neoplastic transformation. Cell Growth Differ. 5: 1389-1394.

Hickman, J.A. 1992. Apoptosis induced by anticancer drugs. Cancer Metastasis Rev. 11: 121-139.

Hockenbery, D.M., Z.N. Oltvai, X.-M. Yin, C.L. Milliman, and S.J. Korsmeyer. 1993. bcl-2 function in an antioxidant pathway to prevent apoptosis. Cell 75: 241-251.

Howes, K.A., N. Ransom, D.S. Papermaster, J.G. Lasudry, D.M. Albert, and J.J. Windle. 1994. Apoptosis or retinoblastoma: Alternative fates of photoreceptors expressing the HPV-16 E7 gene in the presence or absence of p53. Genes \& Dev. 8: $1300-1310$.

Kluck, R.M., E. Bossy-Wetzel, D.R. Green, and D.D. Newmeyer. 1997. The release of cytochrome $\mathrm{c}$ from mitochondria: A primary site for $\mathrm{Bcl} 2$ regulation of apoptosis. Science 275: 1132-1136.

Lazebnik, Y.A., S. Cole, C.A. Cooke, W.G. Nelson, and W.C. Earnshaw. 1993. Nuclear events of apoptosis in vitro in cellfree mitotic extracts: A model system for analysis of the active phase of apoptosis. I. Cell. Biol. 123: 7-22.

Lazebnik, Y.A., S.H. Kaufmann, S. Desnoyers, G.G. Poirier, and W.E. Earnshaw. 1994. Cleavage of poly(ADP-ribose) polymerase by a proteinase with properties like ICE. Nature 371: 346-347.

Liu, X., C.N. Kim, J. Yang, R. Jemmerson, and X. Wang. 1996. Induction of apoptotic program in cell-free extracts: Requirement for dATP and cytochrome c. Cell 86: 147-157.

Lowe, S.W., H.E. Ruley, T. Jacks, and D.E. Housman. 1993. p53-dependent apoptosis modulates the cytotoxicity of anticancer agents. Cell 74: 957-967.

Lowe, S.W., T. Jacks, D.E. Housman, and H.E. Ruley. 1994 Abrogation of oncogene-associated apoptosis allows transformation of p53-deficient cells. Proc. Natl. Acad. Sci. 91: 2026-2030.

Martin, S.J. and D.R. Green. 1995. Protease activation during apoptosis: Death by a thousand cuts? Cell 82: 349-352.

Martin, S.J., D.D. Newmeyer, S. Mathias, D.M. Farschon, H.G. Wang, J.C. Reed, R.N. Kolesnick, and D.R. Green. 1995. Cell-free reconstitution of Fas-, UV radiation- and ceramideinduced apoptosis. EMBO I. 14: 5191-5200.

McCurrach, M.E., T.M.F. Connor, C.M. Knudson, S.J. Korsmeyer, and S.W. Lowe. 1997. Bax-deficiency promotes drug resistance and oncogenic transformation by attenuating p53dependent apoptosis. Proc. Nat1. Acad. Sci. 94: 2345-2349.

Nevin, J.R. 1982. Induction of the synthesis of a 70,000 dalton mammalian heat shock protein by the adenovirus E1A gene product. Cell 29: 913-919.

Nicholson, D.W., A. Ali, N.A. Thornberry, J.P. Vaillancourt, C.K. Ding, M. Gallant, Y. Gareau, P.R. Griffin, M. Labelle, Y.A. Lazebnik, N. Munday, S. Raju, M. Smulson, T. Yamin, V. Yu, and D. Miller. 1995. Identification and inhibition of the ICE/CED-3 protease necessary for mammalian apoptosis. Nature 376: $37-43$.

Oltvai, Z.N., C.L. Milliman, and S.J. Korsmeyer. 1993. bcl2 hetrodimerizes in vivo with a conserved homolog, bax, that accelerates programmed cell death. Cell 74: 609-619.

Rao, L., M. Debbas, P. Sabbatini, D. Hockenbery, S. Korsmeyer, and E. White. 1992. The adenovirus E1A proteins induce apoptosis, which is inhibited by the E1B $19-\mathrm{kDa}$ and $\mathrm{bcl} 2$ proteins. Proc. Natl. Acad. Sci. 89: 7742-7746. 
Sala, A., I. Casella, L. Grasso, T. Bellon, J.C. Reed, T. Miyashita, and C. Peschle. 1996. Apoptotic response to oncogenic stimuli: Cooperative and antagonistic interactions between c-myb and the growth suppressor p53. Cancer Res. 56: 19911996.

Subramanian, T., B. Tarodi, R. Govindarajan, J.M. Boyd, K. Yoshida, and G. Chinnadurai. 1993. Mutational analysis of the transforming and apoptosis suppression activities of the adenovirus E1B 175R protein. Gene 124: 173-181.

Susin, S.A., N. Zamzami, M. Castedo, T. Hirsch, P. Marchetti, A. Macho, E. Daugas, M. Geuskens, and G. Kroemer. 1996. $\mathrm{Bcl} 2$ inhibits the mitochondrial release of an apoptotic protease. J. Exp. Med. 184: 1331-1341.

Thornberry, N.A. 1994. Interleukin-1 beta converting enzyme. Methods Enzymol. 244: 615-631.

Thornberry, N.A., E.P. Peterson, J.J. Zhao, A.D. Howard, P.R. Griffin, and K.T. Chapman. 1994. Inactivation of interleukin-1 beta converting enzyme by peptide (acyloxy/methyl ketones. Biochemistry 33: 3934-3940.

White, E. 1993. Regulation of apoptosis by the transforming genes of the DNA tumor virus adenovirus. Proc. Soc. Exp. Biol. Med. 204: 30-39.

White, E., H. Blose, and B.W. Stillman. 1984. Nuclear envelope localisation of an adenovirus tumor antigen maintains integrity of cellular DNA. Mol. Cell. Biol. 4: 2865-2875.

Xue, D., S. Shaham, and H. Horvitz. 1996. The Caenorhabditis elegans cell-death protein CED-3 is a cysteine protease with substrate specificities similar to those of the human CPP32 protease. Genes \& Dev. 10: 1073-1083.

Yamada, T., S. Yamaoka, T. Goto, M. Nakai, Y. Tsujimoto, and M. Hatanaka. 1994. The human T-cell leukemia virus type I Tax protein induces apoptosis which is blocked by the Bcl2 protein. J. Virol. 68: 3374-3379.

Yang, E., J. Zha, J. Jockel, L.H. Boise, C.B. Thompson, and S.J. Korsmeyer. 1995. Bad, a heterodimeric partner for Bcl-XL and $\mathrm{Bcl} 2$, displaces Bax and promotes cell death. Cell 80: 285-291.

Yang, J., X. Liu, K. Bhalla, C.N. Kim, A.M. Ibrado, J. Cai, T. Peng, D.P. Jones, and X. Wang. 1997. Prevention of apoptosis by Bcl2: Release of cytochrome $c$ from mitochondria blocked. Science 275: 1129-1132.

Zamzami, N., S.A. Susin, P. Marchetti, T. Hirsch, I. Gomezmonterrey, M. Castedo, and G. Kroemer. 1996. Mitochondrial control of nuclear apoptosis. J. Exp. Med. 183: 15331544. 


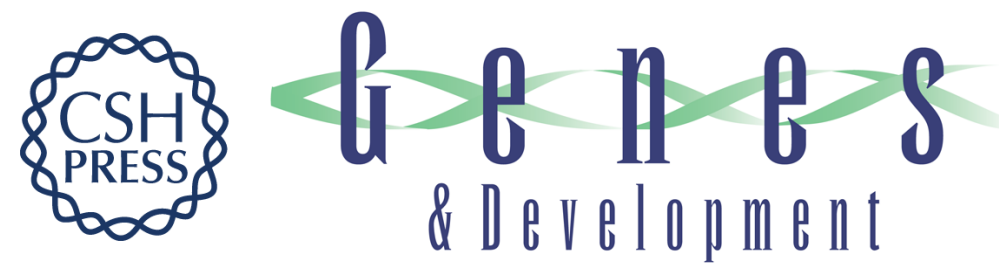

\section{Oncogene-dependent apoptosis in extracts from drug-resistant cells.}

H O Fearnhead, M E McCurrach, J O'Neill, et al.

Genes Dev. 1997, 11:

Access the most recent version at doi:10.1101/gad.11.10.1266

References This article cites 42 articles, 15 of which can be accessed free at:

http://genesdev.cshlp.org/content/11/10/1266.full.html\#ref-list-1

License

Email Alerting

Receive free email alerts when new articles cite this article - sign up in the box at the top Service right corner of the article or click here.

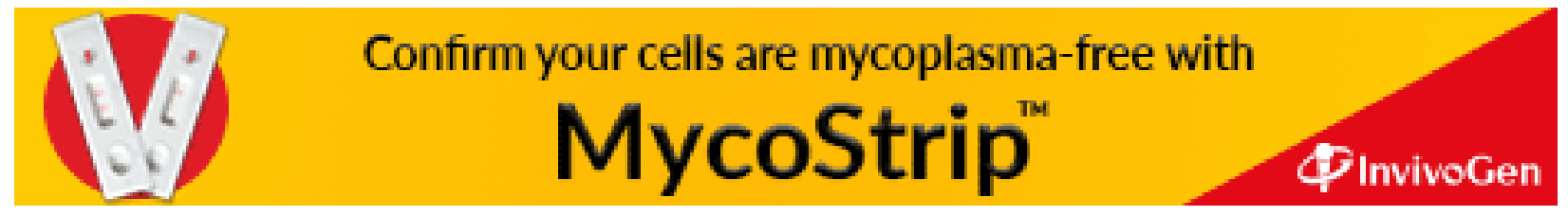

